\title{
KONTINUITAS DAN DISKONTINUITAS \\ PERILAKU KORUPSI DI JAWA*
}

\author{
CONTINUITY AND DISCONTINUITY \\ OF CORRUPTIVE BEHAVIOR IN JAVA
}

\author{
Djoko Dwiyanto dan Riboet Darmosoetopo \\ Jurusan Arkeologi, FIB - UGM \\ djoko.dwiyanto@gmail.com
}

\begin{abstract}
Corruption has become an inherent behaviour at any event in relationship among one and other parties, both transactionally or collusion and gratification. Both inscriptions and textual evidences in Old Javanese to Modern Javanese showed evidence of abuse of authority and irregularities which led to corruption.Usually, corruption occurs because there are chances and opportunities as well as social structures that encourage corruption. Dependency between the parties need 'protection' (clients) with the ruling party with authority (patron), led to the emergence of provision of services or repayment. Gratification is collusive and often involves various areas of life, both socio-economic and socio-cultural.
\end{abstract}

Key words: Corruption, Abuse of authority, and Collution

\begin{abstract}
ABSTRAK
Korupsi telah menjadi perilaku yang melekat pada peristiwa relasi antardua pihak atau lebih, baik bersifat transaksional maupun kolusi dan gratifikasi. Berdasarkan bukti-bukti tertulis berupa prasasti pada masa Jawa Kuna hingga zaman Indonesia modern ternyata telah terjadi penyalahgunaan wewenang dan penyimpangan, sehingga menyebabkan terjadinya korupsi. Korupsi terjadi biasanya karena terdapat peluang dan kesempatan serta struktur sosial masyarakat yang mendukung terjadinya korupsi itu. Ketergantungan antara pihak yang memerlukan 'perlindungan'(klien) dengan pihak yang berkuasa dan memiliki otoritas (patron), menyebabkan munculnya tanda jasa atau balas budi. Gratifikasi sering bersifat kolutif dan menyangkut berbagai bidang kehidupan, baik sosial-ekonomi maupun sosial-budaya.
\end{abstract}

Kata kunci: Korupsi, Penyalahgunaan wewenang, Kolusi

Tanggal masuk : 15 Maret 2014
Tanggal diterima : 5 Mei 2014

* Artikel ini didasarkan atas hasil penelitian yang pernah dilakukan terhadap masyarakat Jawa Kuna dan masyarakat Jawa Modern yang dilaksanakan bersama Prof. Dr. Suhartono Wiryopranoto. Tetapi, yang tersaji dalam artikel ini khusus berbasis pada data yang berasal dari masa Jawa Kuna berdasarkan prasasti. 


\section{PENDAHULUAN}

Salah satu penyakit masyarakat yang selalu aktual sebagai bahan pembicaraan di berbagai lingkungan dan pada aras mana pun adalah korupsi atau belakangan dikenal dengan sebutan tindak pidana korupsi (Tipikor). Bentuk-bentuk korupsi sangat bervariasi dan sangat tergantung dari lingkungan hubungan sosial masyarakat bersangkutan. Pada dasarnya, setiap usaha memanfaatkan kekuasaan untuk menguntungkan diri sendiri atau kelompok dapat dikategorikan sebagai bentuk korupsi. Hal seperti itu memungkinkan jika kekuasaan sudah berada di tangan, maka jalan pintas menuju pemupukan kekayaan terbuka lebar, sehingga bentuk-bentuk korupsi akan terwujud. Selanjutnya, perilaku yang disebut dengan korupsi ini lambat laun, jika tidak dilakukan tindakan, akan menjadi suatu kewajaran dan diterima oleh masyarakat. Hal ini selaras dengan konsep korupsi yang diajukan oleh Peter Bratsis (2003), yang menganggap bahwa korupsi seolah merupakan hasil keterampilan yang menjadi tindakan praktis dan berkembang menjadi kemampuan yang tampak alamiah serta berkembang di lingkungan sosial tertentu, yang tentunya bersikap permisif terhadap tindakan korup tersebut. Sikap masyarakat yang pro hedonisme instan dapat menyuburkan budaya korup atau budaya jalan pintas tersebut. Dengan demikian, orang biasa dan secara moral pun dapat saja terjebak dalam pragmatisme kekuasaan dan birokrasi yang korup.

Sepanjang sejarah kehidupan bangsa ini ternyata upaya pemberantasan korupsi belum juga memberikan hasil yang cukup memuaskan. Kebiasaan korupsi telah terlanjur mengakar dimulai dari lapisan atas yang menggurita hingga ke lapisanlapisan di bawahnya. Kemudian terciptalah interaksi antara lapisan lapisan tersebut menjadi kusut, bahkan menjadi rumit dan kompleks. Pembentukan Tim Pemberantasan Korupsi pada masa Pemerintahan
Presiden Soekarno sampai dengan yang terakhir dikenal sebagai lembaga yang bernama Komisi Pemberantasan Korupsi (KPK), mengalami banyak kendala dalam aksinya. Di dalam upaya pemberantasan korupsi diperlukan konsistensi dan keuletan tersendiri, mulai dari lapisan paling atas dari pemerintahan, pengadilan, dan juga didukung dari bawah, yaitu masyarakat sendiri. Perbedaan persepsi dalam penyelesaian kasus-kasus korupsi juga turut memperkeruh keadaan. Sebagai akibat akumulasi waktu penyelesaian perkara korupsi, muncul kecenderungan untuk bertindak cepat, keras dan tegas, tetapi ternyata selalu dihadapkan pada kenyataan bahwa proses hukum yang benar dan adil memerlukan waktu yang relatif lama. Pada titik inilah muncul ketidaksabaran dari berbagai kalangan, yang pada akhirnya justru menghambat proses penindakan terhadap kasuskasus korupsi di Indonesia.

Keseriusan pemerintah dan kepedulian masyarakat dalam menangani pemberantasan korupsi sangatlah diperlukan. Konsistensi dan keseriusan pemerintah dalam menindak kasus korupsi secara tidak pandang bulu akan semakin memperbesar rasa kepercayaan masyarakat. Semestinya kepercayaan tersebut akan diikuti dengan kepedulian dari masyarakat untuk berpartisipasi dalam pemberantasan korupsi di lingkungan sekitar masyarakat sendiri.

Berdasarkan argumentasi itu, maka perlu dikaji fenomena tindak pidana korupsi di kalangan masyarakat, khususnya pada masa Jawa Kuna yang keberlangsungannya sangat boleh jadi hingga jaman modern. Penelitian terhadap masyarakat Jawa Kuna dilakukan dengan cara melakukan inventarisasi terhadap berbagai bentuk korupsi yang tercermin dalam hubungan sosial antarmasyarakat pada masa Jawa Kuna seperti terlihat dalam prasasti-prasasti. Oleh karena itu, sebagai gambaran awal tentang perilaku korupsi berdasarkan data tertulis akan dicoba dikaji dalam penelitian ini agar dapat diketahui penyebab, konteks 
terjadinya korupsi, dan solusi yang diambil dalam menghadapi kasus semacam itu. Hasil dari pemahaman terhadap informasi dan pembelajaran yang diperoleh dari prasasti diharapkan dapat diketahui arti pentingnya warisan budaya nenek moyang, sebagai suatu kearifan budaya. Salah satu upaya itu dilakukan dengan cara menginventarisasikan berbagai bentuk-bentuk korupsi yang tercantum dalam kalimat-kalimat prasasti yang berasal dari periode Jawa Tengah pada masa sekitar abad ke-8 sampai dengan ke-10 Masehi. Peristiwaperistiwa itu tercatat dalam prasastiprasasti yang terdapat dan tersebar di seluruh wilayah Jawa Tengah. Jika teksteks dalam prasasti itu dapat diinterpretasikan sebagai gambaran masyarakat pada masa itu, maka dapat diketahui bahwa perilaku korupsi memang telah pernah berlangsung pada masa Jawa Kuna.

Penelitian ini dilaksanakan dengan cara menafsirkan kalimat-kalimat prasasti yang berisi peristiwa hubungan sosial dan ekonomi masyarakat yang dapat dikategorikan sebagai tindak pidana korupsi. Penelitian dengan pokok bahasan seperti ini jarang atau belum pernah dilakukan dengan berbagai alasan, antara lain keterbatasan sumber daya yang dapat mengkaji prasasti sebagai sumber sejarah. Penelitian prasasti misalnya, umumnya berupa penelitian filologis, linguistik, dan historis yang bersifat deskriptif analitik. Prasasti sebagai sebuah teks dikaji berdasarkan pendekatan filologis (sifat dan karakter teks), pendekatan linguistik (kebahasaan yang ada dalam prasasti), atau pendekatan historis, yaitu isi prasasti digunakan sebagai sumber penulisan sejarah. Penelitian ini diharapkan dapat membuat deskripsi secara lebih mikro tentang bentukbentuk korupsi pada masyarakat Jawa Kuna yang terjadi sekitar abad ke-8 sampai dengan ke-16 Masehi, terutama difokuskan antara abad ke-8 sampai ke10 , yang sering dikenal sebagai periode Jawa Tengah.

Sementara itu, berdasarkan penelitian yang pernah dilakukan terhadap masyarakat Jawa modern dapat diketahui bahwa kejahatan korupsi terjadi dan berlangsung lama dalam setiap lini kehidupan sejalan dengan melemahnya hukum yang ada di Indonesia. Perilaku korupsi dulu dan kini tetap saja merupakan bagian dari budaya yang memerlukan penjelasan bagaimana genesis dan perkembangannya. Pada akhirnya, terciptalah kondisi Indonesia yang sudah tidak asing lagi dengan mendapat "predikat" negara terkorup di dunia. Di dalam praktik tindak pidana korupsi bukan hanya terjadi secara institusional, tetapi juga sudah terjadi secara kolektif dan individual, serta membentang dan menbentuk sebuah jaringan yang saling mendukung di berbagai sektor kehidupan. Berdasarkan kenyataan ini lah kemudian menjadikan Indonesia termasuk dalam sepuluh besar negara terkorup di dunia. Mentalitas dan warisan-warisan budaya feodal masa lalu terutama pada masyarakat Jawa adalah bagian terpenting dalam pembentukan karakter dan perilaku manusia Indonesia.

Berdasarkan pengamatan awal dapat diketahui bahwa perilaku korupsi dapat terjadi karena dipengaruhi oleh berbagai faktor, di antaranya adalah faktor kesempatan, peluang, dan rendahnya moralitas yang menjadi alasan mengapa seorang oknum melakukan tindak pidana korupsi. Kenyataan ini menimbulkan pertanyaan mendasar sebagai berikut: mengapa praktik-praktik korupsi terus berlanjut di kalangan masyarakat Indonesia? Faktor-faktor apa yang menyebabkan terus terpeliharanya praktik korupsi di kalangan masyarakat Indonesia? Apakah benar bahwa tradisi budaya kolonial yang terwarisi dan mentalitas sumber daya manusia yang rendah mendorong mereka untuk melakukan korupsi? Bagaimana wujud pencegahan yang telah dilakukan oleh pihak pemerintah zaman Jawa Kuna dan pemerintah kolonial untuk mereduksi korupsi? Pertanyaan-pertanyaan tersebut menjadi acuan yang ditelusuri agar ditemukan jawaban melalui penelitian ini. 
Seperti telah disebut di bagian terdahulu, penelitian ini semula merupakan gabungan dari dua penelitian yang berbeda dalam dimensi $-10$ waktu dan penggalian sumber datanya. Penelitian korupsi pada masyarakat Jawa Kuna menggunakan data utama berupa prasasti-prasasti yang berbahasa Jawa Kuna periode Jawa Tengah dari abad ke-8 hingga ke-10 Masehi. Sementara itu, penelitian korupsi pada masyarakat Jawa Modern menggunakan sumber tertulis, yang berupa sumber arsip-arsip berbahasa Belanda, majalah-majalah, dan korankoran yang terbit dalam kisaran abad ke-20. Oleh karena itu, sebelum membandingkan kedua kondisi dari dua periode yang berbeda jauh tipologi masyarakatnya itu diperlukan pendekatan yang spesifik, yaitu perbandingan/komparasi kasus dalam masyarakat yang berbeda tipologi dan jiwa zamannya.

Selanjutnya pendekatan ini akan digunakan sebagai alat analisis terhadap kedua permasalahan yang dirumuskan dalam penelitian ini. Perbandingan kedua perilaku korupsi antara masyarakat Jawa Kuna dan Jawa Modern merupakan bagian terbesar yang mendominasi pola dan kehidupan kaum birokrat di Jawa pada khususnya dan di Indonesia pada umumnya.

\section{METODE KAJIAN KORUPSI BERBASIS SUMBER TEKSTUAL}

Penelitian tentang korupsi pada masyarakat Jawa Kuna menggunakan data utama berupa prasasti-prasasti yang berbahasa Jawa Kuna abad ke-8 sampai ke-16 Masehi, secara khusus periode Jawa Tengah abad ke-8 hingga ke-10 Masehi. Sementara itu, pada kesempatan lain dilanjutkan dengan penelitian korupsi pada masyarakat Jawa Modern dengan menggunakan sumber tertulis, maka berupa sumber arsip-arsip berbahasa asing (Belanda), majalah-majalah, dan koran-koran yang terbit dalam kisaran abad ke-20 Masehi. Oleh karena itu, sebelum dilakukan perbandingan terhadap dua kondisi, dalam dua periode yang berbeda jauh tipologi masyarakatnya, masing-masing juga digunakan metode yang berbeda untuk mengungkapkan permasalahan yang diteliti. Pada tulisan ini merupakan bagian awal, sehingga perlu dilakukan kajian terhadap fenomena korupsi yang terjadi pada masa Jawa Kuna dengan menggunakan Metode Epigrafi. Pendekatan kajian epigrafis, yaitu salah satu cabang ilmu dalam arkeologi, secara khusus memiliki karakteristik dalam penelitiannya. Metode penelitian epigrafi sekurang-kurangnya terdapat tiga model yang cukup dikenal, yaitu (1) penelitian analitis dengan pendekatan struktural, (2) penelitian sintesis melalui pendekatan fungsi-fungsi kebudayaaan, dan (3) penelitian gabungan antara penelitian analitis dan sintesis (Dwiyanto 1993, 7). Penelitian analitis dengan pendekatan struktural meliputi tahap pra-analitis yang mencakup dua hal, yaitu kritik eksternal dan kritik internal. Kritik eksternal meliputi deskripsi benda, aksara, lancana, dan pemilik. Kritik eksternal ini pun dapat diterapkan pada artefak non prasasti atau naskah. Sementara itu, kritik internal mencakup transliterasi (alih aksara) dan transkripsi (terjemahan). Hasil pra-analitis kritik eksternal berupa analisis bentuk atau jenis, bahan, dan aksara, selanjutnya dapat diperoleh penafsiran yang bersifat kronologis. Pra-analisis kritik internal akan menghasilkan analisis identitas melalui pesan atau isi prasasti, berupa penafsiran aspek ekonomi, sosial, birokrasi, dan hukum.

Di dalam penelitian sintesis melalui pendekatan fungsi-fungsi kebudayaan digunakan analisis fungsi kebudayaan dengan komparatif struktural (structural comparative) yang menghasilkan analisis dengan dasar ekonomi, kesenian, teknologi, bahasa, dan agama sebagai aspek dalam penggambaran masyarakat pendukung kebudayaan itu, dalam hal ini adalah perilaku korupsi. Selanjutnya, untuk memberikan penafsiran terhadap hasil kajian epigrafis terhadap topik perilaku korupsi juga digunakan metode hermeneutik. Metode ini diharapkan 
dapat menjelaskan penafsiran terhadap suatu teks yang dilakukan oleh penafsir dengan menyadari bahwa dirinya sendiri di tengah-tengah sejarah yang menyangkut baik penerimaan maupun penafsiran, serta cara mengerti sebuah teks yang turut dihasilkan tradisi. Penafsiran terjadi sambil meleburkan cakrawala masa silam dan masa kini (Sumaryono 1999, 29). Penafsir harus memahami teksnya dan menerapkan teks yang kaku dan lepas dari keterkaitan waktu pada situasinya sendiri.

\section{BAHAN DAN ALAT PENELITIAN}

Seperti disebutkan di muka, bahwa data utama dalam penelitian ini adalah berupa prasasti-prasasti yang berbahasa Jawa Kuna dan secara kronologis berasal dari periode Jawa Tengah dan Jawa Timur sekitar abad ke-8 sampai ke-16 Masehi. Prasastiprasasti itu terutama yang telah dibaca dan/atau diterbitkan agar diperoleh gambaran lebih jelas dalam analisisnya. Berdasarkan isi prasasti-prasasti itu dapat diketahui berbagai peristiwa yang mengiringi penetapan suatu daerah menjadi sîma, karena seringkali dijadikan alasan atau sambandha. Struktur isi prasasti-prasasti itu pada umumnya sudah lengkap, berisi mengenai penetapan suatu daerah menjadi sîma disertai alasan penetapannya, sehingga dapat diketahui peristiwa apa yang diperingati dalam prasasti itu. Alasan penetapan prasasti atau sambandha itu secara kontekstual dapat memberikan gambaran tentang masyarakat yang sedang terlibat dalam penetapan sîma, atau daerah perdikan.

Selain alat tulis-menulis sebagai peralatan penelitian prasasti, juga digunakan kaca pembesar dan abklats untuk pembacaan langsung terhadap prasasti, jika belum jelas dan diperlukan konfirmasi ulang, serta peralatan fotografi untuk mendokumentasikan prasasti terutama yang masih berada di tempatnya (in-situ).

\section{PELAKSANAAN PENELITIAN}

Penelitian korupsi melalui sumber tekstual berupa prasasti diawali dengan pengumpulan data, baik melalui sumber pustaka maupun observasi langsung ke lapangan. Data berupa prasasti diklasifikasi berdasarkan peristiwa yang melatarbelakangi penetapannya. Prasasti-prasasti periode Jawa Tengah dan Jawa Timur pada umumnya telah dikumpulkan dan diterbitkan dalam sebuah kumpulan prasasti, kecuali penemuan prasasti baru yang belum terbaca biasanya disimpan di kantor instansi pemerintah (Dinas Pendidikan dan Kebudayaan atau Balai Pelestarian Cagar Budaya wilayah Jawa Tengah dan Jawa Timur). Informasi tentang alasan penetapan suatu sîma, daerah perdikan, yang disebut sambandha, dituliskan pada sebuah kartotik untuk memudahkan klasifikasi. Selanjutnya, dilakukan analisis terhadap kalimat yang diduga terkait dengan kasus korupsi yang tertuang dalam prasasti bersangkutan. Analisis itu dapat memberikan kontribusi pemetaan permasalahan dan bentuk-bentuk korupsi pada masayarakat Jawa Kuna.

Analisis terhadap data yang ditemukan dalam kalimat-kalimat prasasti dilakukan secara kualitatif, baik terhadap prasasti maupun isinya. Prasasti dianalisis terhadap informasi tentang peristiwa yang diperingati dan selanjutnya dikaji dampak peristiwa itu terhadap adanya unsur penyimpangan atau tindak pidana korupsi. Hasil analisis ini kemudian juga dituliskan pada sebuah kartotik untuk mempermudah pembahasan lebih lanjut dikaitkan dengan setting masyarakat yang sedang melakukan upacara penetapan sîma. Berdasarkan hasil analisis itu kemudian dilakukan penempatan atau kategorisasi berdasarkan besar kecilnya kerugian yang ditangung oleh negara maupun masyarakat masa Jawa Kuna.

\section{Berdasarkan}

pemahaman

terhadap landasan pemikiran bahwa pemuatan peristiwa 'korupsi' dalam sebuah prasasti penetapan sîma yang dianggap sebagai sesuatu yang istimewa, maka kajian ini dirancang 
sebagai sebuah penelitian bersifat historis yang penekanannya pada perspektif budaya.

Di dalam metode penelitian sejarah (Garraghan 1957, 27), beberapa langkah yang ditempuh dalam rangkaian sistemik dan proses pengumpulan data, antara lain:

1. Heuristik, yaitu metode pengumpulan dan penyeleksian sumber-sumber sejarah.

2. Kritik, yaitu metode kritik terhadap sumber-sumber sejarah, meliputi kritik ekstern dan juga kritik intern.

3. Auffasung, analisis; dalam proses analisis diperlukan perangkat ilmu bantu, interpretasi dan imajinasi untuk menjelaskan fenomenafenomena yang ada dalam sumber yang digunakan.

4. Darstellung, penulisan; dengan memperhatikan kronologis dan penjelasan yang akurat berdasarkan sumber-sumber yang telah dianalisis (Moore 1965, 83).

Oleh karena itu, dalam penelitian awal adalah pengumpulan data dilakukan dengan metode heuristik terhadap prasasti-prasasti berbahasa Jawa Kuna abad ke-8 hingga ke-16. Berdasarkan penelusuran dan pelacakan sumber ini diharapkan dapat diungkapkan sistem nilai budaya dan gagasan serta kajian mengenai korupsi yang terjadi pada masa Jawa Kuna, khususnya periode Jawa Tengah. Data dari sumber tertulis yang diperoleh, selanjutnya akan diverifikasi dan kemudian diadakan analisis, yang pada akhirnya disajikan dalam bentuk ekplanasi.

Proses penelitian ini dirangkai dan dibagi dalam beberapa tahapan, sebagai berikut.

1. Tahap persiapan yang dilakukan dalam bentuk pengumpulan bahanbahan dan sumber penelitian, penyempurnaan kerangka konseptual dan rencana kegiatan penelitian lapangan;

2. Tahap penelusuran bahan-bahan pustaka untuk penyempurnaan desain penelitian dan beberapa terminologi korupsi;

3. Tahap perumusan instrumen penelitian (sumber-sumber pustaka yang terkait);

4. Tahap pengolahan dan analisis data yang merupakan uraian untuk menjawab yang diteliti;

permasalahan

5. Tahap penulisan laporan penelitian berdasarkan temuan dari sumber tertulis;

6. Seminar terbatas dilakukan untuk penyempurnaan draft laporan penelitian;

7. Tahap penyelesaian laporan akhir.

\section{KONTINUITAS DAN DISKONTINUITAS KORUPSI PADA MASA JAWA KUNA}

Di dalam pemahaman awal sebuah fenomena korupsi, asumsi yang digunakan adalah suatu tindakan yang mencari keuntungan sepihak, dengan metode dan cara tertentu, bersifat mencari keuntungan, tanpa memperhatikan pihak yang dirugikan dan akibat yang ditimbulkan. Menurut Deflem (1995, 246), korupsi (corruption) adalah "the offering and accepting of bibes" (penawaran/pemberian dan penerimaan suap) yang dapat menyebabkan kebusukan atau kerusakan (corruptionist decay). Sudah barang tentu yang dimaksudkan "busuk" atau "rusak" itu, ialah moral atau akhlak dari oknum yang melakukan perbuatan korupsi tersebut. Kubiak (2001), seperti disebut dalam tulisan Baharudin Lopa (2002), David M. Chalmers (1997), menguraikan pengertian korupsi dalam berbagai bidang antara lain yang menyangkut masalah penyuapan, yang berhubungan dengan manipulasi di bidang ekonomi, dan yang menyangkut bidang kepentingan umum (Lopa 2002, 14).

Fenomena korupsi di Indonesia sudah menjadi perhatian sangat serius dari berbagai kalangan dan menjadi perdebatan di kalangan penegak hukum dan masyarakat. Korupsi sekarang sudah mengakar karena sejak zaman kerajaan dan zaman kolonialisme di 
Indonesia sudah banyak dilakukan. Secara kronologis korupsi yang terjadi khususnya di Indonesia berhubungan dengan struktur masyarakat, yang keberlangsungannya secara sosiokultural hampir tidak mengalami perubahan secara signifikan. Dapat dikatakan bahwa sistem sosial masyarakat feodal yang terwarisi sampai sekarang merupakan benih awal bersemainya penyakit sosial ini. Hal ini disebabkan karena kokohnya birokrasi kerajaan didukung oleh sistem sosial feodal yang berlaku dan berakar dalam masyarakat. Birokrasi tradisional yang dibina oleh kerajaan-kerajaan khususnya kerajaan agraris feodal, telah memberi dasar pemerintahan kerajaan yang berlaku di seluruh nusantara (Suhartono 2004, 23).

Beberapa model analisis untuk menghubungkan korupsi dalam wacana kriminologi, dapat disebutkan sebagai berikut. Pertama, analisis berdasarkan teori anomi. Pendekatan ini menyatakan bahwa kejahatan dalam masyarakat terjadi karena struktur masyarakat menyediakan sarana yang sudah melembaga serta tujuan atau cita-cita yang sudah membudaya. Cita-cita, tujuan, atau aspirasi itu ialah kesempatan memperoleh pendidikan yang tinggi, pekerjaan, penghidupan yang tetap atau layak. Kedua, analisis berdasarkan teori asosiasi diferensial. Pendekatan ini menolak pandangan yang menyatakan bahwa kejahatan adalah milik kaum papa untuk selamanya. Dengan kata lain, teori ini menunjukkan bahwa kejahatan juga sering dilakukan oleh kalangan masyarakat elit atau golongan ekonomi kuat. Namun, pelaku kejahatan dari golongan kaya atau "bandit berdasi" ini jarang sampai ke arena sidang pengadilan, sehingga tidak dapat diketahui oleh publik. Ketiga, analisis berdasarkan teori differential acces to opportunity structure. Teori ini menjelaskan bahwa kejahatan terjadi karena adaptasi atas sarana yang dapat mewakili aspirasinya, dan karena reaksi atas ketimpangan atau ketidakadilan dalam kehidupan layak di masyarakat. Keempat, analisis berdasarkan teori labeling. Analisis ini menjelaskan bahwa kejahatan dapat terjadi akibat proses stigmatisasi sosial, yaitu proses krisis identitas mengenai jati diri seseorang di tengah-tengah masyarakat. Stigmatisasi ini terjadi karena persepsi atau konstruksi masyarakat, termasuk konstruksi oleh pemerintah atau aparataparat penegak hukum. Proses stigmatisasi ini kebanyakan dialami oleh mantan-mantan narapidana yang sebenarnya telah memperoleh hak bebas dan hak hidup di tengah-tengah masyarakat normal. Pendekatan analisis teoretik ini berlaku untuk fenomena umum yang dikenal dengan sebutan kejahatan. Korupsi adalah bagian dari kejahatan manusia, maka perbincangan tentang korupsi secara otomatis berlaku juga, karena teori-teori ini universal pada berbagai jenis motif dan modus operandi kriminalitas.

Oleh karena itu, tidak terlalu menyimpang jika seorang tokoh pembaharu dari Cina mengatakan bahwa sepanjang perjalanan sejarah, banyak hal telah berulang. Demikian pula, fenomena korupsi menurut Wang An Shih (1021-1086), dalam usahanya memberantas korupsi terkesan oleh dua sumber korupsi yang senantiasa berulang, yaitu buruknya penegakan hukum dan buruknya manusia (Alatas 1986, 42).

Seperti telah diketahui, bahwa fenomena korupsi telah lama menjadi bahan kajian yang menarik minat berbagai kalangan. Unsur yang menarik dari fenomena korupsi secara historis bahwa telah terjadi pada masa kerajaankerajaan dan pemerintahan kolonial. Bahkan, tidak terduga sebelumnya warisan-warisan masa lalu ternyata tidak hanya menjadi bagian dari sejarah, namun juga meninggalkan budaya yang mengarah untuk memperkuat korupsi. Realitas yang terjadi, misalnya feodalisme tradisional versus kolonialisme yang berkolaborasi malah memberi peluang ke arah perilaku korupsi. Pokok bahasan tentang korupsi khususnya, sudah banyak ditulis dalam buku-buku maupun penelitian terdahulu, tetapi masih jarang sekali yang mengupasnya dalam perspketif historis 
dan kultural. Penelitian ini memfokuskan penelitian sejarah dengan pendekatan budaya yang prosesual. Secara historis budaya feodal yang mengakar pada 栾@ masa lalu membentuk watak dan perilaku pejabat, pegawai, dan pribadi yang terkait dengan birokrasi di struktur pemerintahan kerajaan.

Penelitian tentang bentuk-bentuk korupsi pada masyarakat Jawa Kuna secara khusus memang belum pernah dilakukan. Tetapi, penelitian tentang aspek-aspek ekonomi dalam masyarakat Jawa Kuna telah banyak dilakukan. Beberapa penelitian itu misalnya penelitian tentang pasar (Nastiti 1986), kerakaian (Richardiana 1992), pajak (Suhadi 1989), dan pajak dan pembatasan usaha (Dwiyanto 1992). Tetapi, di antara penelitianpenelitian itu tidak banyak yang menyinggung secara khusus bentuk korupsi pada masyarakat kuna. Salah satu karya yang menyinggung tentang perbuatan menyimpang adalah tentang pungutan pajak dan pembatasan usaha di Jawa abad ke-9 hingga ke-16 Masehi (Dwiyanto 1992, 42). Hasil analisis dari penelitian itu antara lain menunjukkan adanya kasus-kasus penyalahgunaan pajak. Kasus penyalahgunaan pajak itu antara lain ditunjukkan dengan keinginan/kemauan pejabat yang berwenang untuk meminta pajak lebih dari yang seharusnya dengan cara memanipulasi luas tanah yang dikenai pajak. Kasus di atas terdapat dalam prasasti Tija yang berkaitan dengan kasus Rakryan Jasun Wungkal. Kutipan kalimat dalam prasasti Tija adalah sebagai berikut.

2. ...pan nayaka para ni sadrwya haji nikang sîma kawajwan ling rakryan jasu

3. n wungkal, tinañan pwekang awaju ri manayuti mangaran wasana dinamwan de çri mahârâja ri para ni drwya haji nikang sîma

4. kawajwan ri tija.....

5. ...pinaka pangiwönya irikang pangurang angas wuwuh lingnya. tan tinahilakênnya ring nayaka mithya ta ngaran ika ra-

6. kryan jasun wungkal yang panêngguh mareng nayaka drwya haji nikang sîma kawajwan ri tija....dst.

Artinya:

2. kepada para pegawai kerajaan (nayaka) dalam daerah perdikan (sîma) termasuk Rakryan Jasu

3. n Wungkal, ditanyakan kepada Awaju di Manayuti yang bernama Wasana dan Dinamwan oleh Sri Maharaja kemana (aliran) pajak dari sîma

4. Kawajwan di Tija.

5. sebagai jamuan bagi petugas penarik pajak atas kegiatan/ tugasnya. tidak dialihkan

(diserahkan) oleh para pegawai kerajaan yang bernama ra-

6. kryan Jasun Wungkal yang seharusnya menerima dari pegawai kerajaan pajak (drwya haji $=$ milik/hak raja) atas sîma Kawajwan di Tija. (Terjemahan oleh: Penulis).

Di satu pihak, ada laporan bahwa pajak di Tija tidak diserahkan kepada nayaka, yang tentunya juga termasuk Rakryan Jasun Wungkal. Kemudian Sri Maharaja memanggil Awaju di Manayuti yang bernama Wasana dan Dinamwan untuk menanyakan perihal pajak tersebut. Selanjutnya, oleh Awaju dikatakan bahwa pajak tersebut digunakan untuk menjamu pangurang (penarik pajak ?) yang meminta lebih dari yang semestinya, sehingga akhirnya tidak diserahkan kepada nayaka. Di dalam kasus ini ketidakjujuran pangurang dapat dikategorikan sebagai tindak pidana korupsi, karena sebagai pegawai kerajaan semestinya ia sudah menerima gaji tetap, tetapi ternyata masih meminta bagian dari pembayaran pajak. Penafsiran terhadap kasus-kasus sejenis itu masih dapat dilakukan terhadap peristiwa-peristiwa yang terkait dengan perpajakan, misalnya pajak 
kewarganegaraan (orang asing), sengketa tanah, pajak penjualan, pajak usaha, dan pajak exit-permit. (Boechari 1975, 80)

\section{Penelitian-penelitian}

tentang

korupsi yang terjadi akhir-akhir ini pada umumnya difokuskan pada besaran kerugian negara, tindak pidana pelaku, dan aspek-aspek hukum lainnya. Penelitian semacam itu seyogyanya juga dilengkapi dengan kajian dari aspek budaya, misalnya latar belakang munculnya tindak pidana korupsi atau sebab-sebab tindakan korupsi. Selain itu juga perlu diinventarisasikan bentukbentuk korupsi pada masa Jawa Kuna sebagai referensi dan inspirasi cara pencegahan, penanggulangan, dan pemulihannya. Di antara karya-karya yang membahas tentang aspek sosialekonomi dari sumber prasasti tidak ada yang secara khusus memfokuskan diri pada masalah korupsi. Oleh karena itu, hasil penelitian ini diharapkan dapat memperkaya khasanah hasil penelitian tentang masyarakat Jawa Kuna yang bersumber dari prasasti, selain yang pernah ada misalnya tentang perbanditan pada masa Jawa Kuna (Boechari 1992).

Salah satu tulisan dari Boechari (1975) tentang pelaksanaan hukum dalam masyarakat Jawa Kuna telah memperkuat data tentang aspek penyelewengan, penindakan, keputusan hukum, dan lembaga peradilan yang ada. Sumber-sumber tertulis yang berisi informasi itu diperoleh dari data prasasti dari masa Singasari dan Majapahit, mengingat pada kurun waktu ini cukup banyak prasasti yang berisi keputusan hukum yang diterbitkan. Prasasti yang memuat tentang keputusan hukum menurut Boechari adalah sesuatu yang istimewa. Artinya, sebegitu istimewanya kasus tersebut sehingga perlu diperkuat dengan diterbitkannya sebuah prasasti dan tidak hanya cukup berdasarkan pada kitab hukum perundangan yang ada pada saat itu. Tetapi, hingga saat ini belum diperoleh data yang menyebutkan tentang jalannya proses peradilan pada masa Jawa Kuna. Di dalam tulisan ini disinggung berbagai kasus persengketaan yang berkaitan dengan masalah tanah, pajak, maupun wewenang dan kekuasaan pejabat atas suatu wilayah yang tentunya akan bermuara pada aspek penyalahgunaan wewenang dan jabatan serta merugikan masyarakat maupun kerajaan. Hal ini menyiratkan bahwa suatu keputusan yang telah diatur di dalam kitab perundang-undangan yang ada, dapat saja masih menyisakan permasalahan di antara pihak yang bersengketa. Oleh karena itu, perlu diterbitkan prasasti oleh raja demi memperkuat putusan hukum yang telah dibuat oleh lembaga peradilan dan mempunyai kekuatan hukum yang mutlak/tetap. Selain itu, prasasti yang bernuansa hukum juga memuat bentuk sengketa yang tidak diatur dalam undang-undang. Penyelesaian perkara pun juga dapat dibagi ke dalam tingkat-tingkat. Di mulai di tingkat peradilan daerah untuk kasus hutang piutang, hingga ke peradilan tingkat pusat bahkan diputuskan oleh sang raja sendiri bagi kasus besar seperti hak atas tanah, bangunan suci, pajak, dan perdikan.

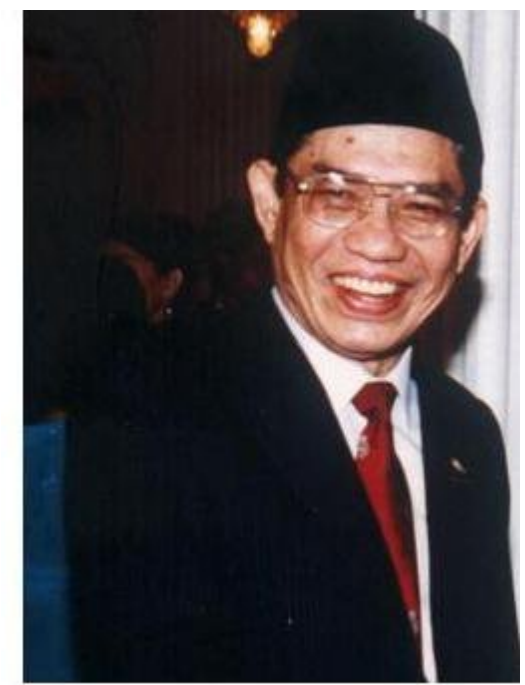

Gambar 1. Foto Baharudin Lopa salah satu tokoh Penegak Hukum di Indonesia

(Sumber: tokohindonesia.com)

Baharudin Lopa (2002) pernah menulis buku berjudul Kejahatan Korupsi dan Penegakan Hukum, yang memberikan gambaran tentang bagaimana korupsi dalam perspektif hukum. Tulisan ini adalah bunga rampai dari tulisan-tulisannya yang pernah 
dimuat di Surat Kabar Harian Kompas. Buku ini adalah contoh yang sangat baik tentang kajian korupsi di Indonesia dari perspektif hukum. Baharuddin Lopa I $($ adalah seorang tokoh penegak hukum dengan sosok yang tegar dan teguh di negara ini dalam memperjuangkan penegakan hukum.

Syed Hussein Alatas (1986) dalam Sosiologi Korupsi, menggambarkan korupsi sebagai sebuah pengantar untuk melihat dan menganalisis lebih jauh seperti apa sebetulnya korupsi itu. Buku ini juga bagian dari penjelasan tentang korupsi yang menggunakan pendekatan sosiologis. Di dalam buku ini setidaknya juga memberikan pengantar tentang pemahaman awal mengenai seluk-beluk penyakit sosial yang menggejala di Indonesia tersebut.

Bahasan lain yang cukup menarik adalah uraian dari J.E. Sahetapy, yang meskipun secara tersamar kejahatan itu dilakukan para elite, tetapi kejahatan itu dilakukan secara korporatif (Sahetapy, 1994: 12). Namun demikian, siapa yang melakukan kejahatan korporatif tentunya juga "petinggi" yang nota bene adalah para elite. Rouffaer menyebut lebih dari empat puluh jenis sumbangan yang dapat dikategorikan sebagai pendorong korupsi (dalam Bourguignan 1992, 41). Sumbangan itu, dikirimkan kepada patron mereka khususnya di kerajaan Surakarta dan Yogyakarta. Apa yang dikirimkan kepada patron itu sudah mentradisi yang dilakukan secara reguler dan juga insidental. Oleh karena itu, sumbangan itu kemudian bercampur antara upeti, sumbangan wajib, dan sumbangan sukarela. Meski beban kawula sangat berat, tetapi hal itu sudah mentradisi. Hal ini bukan saja berlaku bagi para petani kepada penguasa lokal, tetapi juga dari penguasa yang lebih rendah kepada penguasa yang lebih tinggi, yang akhirnya berpusat pada raja. Realitas demikian merupakan temuan awal dalam pembahasan untuk menemukan akar dan budaya yang mengalir dan menciptakan hasrat dan keinginan untuk korupsi.

Beberapa kriminolog menulis tentang "Kejahatan Kerah Putih", meskipun pendekatannya dari segi kriminologi, tetapi aspeknya bermacammacam, ada yang mendekati permasalahan melalui aspek yuridis, psikologis, sosiologis, dan historis, sehingga memperjelas masalah kejahatan kerah putih itu. Salah satu dari artikel dalam jurnal itu, adalah karya Sahetapy (2005) "White-Collar Crime: Suatu Pespektif Viktimologi". Artikel itu memberi gambaran bagaimana korupsi yang dilakukan para elite sebagai kejahatan yang mengatasnamakan posisi pekerjaannya, sehingga mereka mendapat legalisasi atas tindakannya. Darmawan (2005) dengan artikelnya berjudul "White-Collar Crime, Arti dan Perluasan Konsep", mengetengahkan makna korupsi dan konsep-konsep lain yang mendukung perbuatan korupsi tersebut. Pada bagian lain, J. Sutoyo dan A. Meliala menulis artikel berjudul "Politik Kejahatan terhadap pelaku White Collar Crime", lebih mengkhususkan pada politik sebagai bagian penting bagi elite untuk bertindak korupsi. Beberapa artikel di atas sangat membantu mempertegas masalah kultural yang terkait dengan korupsi.

Interaksi budaya dan pusat budaya diuraikan pada karya Redfield (1953 dalam Moore 1965), Peasants and Peasant Community yang membagi dua pusat budaya, yaitu budaya kraton dan budaya wong cilik atau dengan istilah lain disebut budaya besar dan budaya kecil. Fenomena interaksi dua pusat budaya terjalin kehidupan masyarakat dengan memelihara budayanya masing-masing. Hubungan itu dipertegas dalam bentuk patron-klien di bidang politik, sosial-ekonomi, dan budaya. Gambaran wong cilik yang ada di struktur sosial bawah tidak dapat bergerak bebas dan harus melayani penguasa atau bangsawan.

Perhatian terhadap budaya ini juga ditulis oleh Umar Khayam (1991), yang menegaskan bahwa transformasi budaya sangat bermanfaat bagi perubahan perilaku budaya. Selanjutnya, perubahan moralitas dan tingkah laku para panutan akan menghasilkan rendahnya aktivitas 
korupsi meski dengan cara sangat evolusioner. Onghokham (1975), menyebutkan bahwa hubungan patronklien sekilas memiliki hubungan saling menguntungkan, tetapi pada kenyataannya para klien diharuskan mengumpulkan dana untuk kepentingan patron. Kerhasilan para klien untuk mengumpulkan dana yang kemudian dipasok sebagai upeti ini disebabkan desentralisasi yang diberikan oleh pusat kerajaan. Faktor inilah yang menyebabkan korupsi dilakukan secara hirarkhis oleh penguasa-penguasa di desa, tetapi sebaliknya petani yang terus menderita sebagai akibat pengumpulan upeti.

Gambaran yang menarik dan juga mendukung untuk melihat fenomena korupsi berasal dari Global Programme Against Corruption Conferences yang bertajuk Prevention: An Effective Tool to Reduce Corruption. Di dalam program ini dibahas sedemikian rupa korupsi dan prinsip-prinsip strategi yang berwenang menanggulanginya serta strategi integritas. Buku ini cukup baik sebagai model pembelajaran yang memuat dimensi kerangka acuan dan teoretik. Upaya yang lebih tepat adalah melihat akar masalah dan budaya yang terjadi, yang dapat melahirkan rumusan berupa konsep untuk mereduksi korupsi.

Berdasarkan berbagai kajian ilmiah tentang korupsi di atas, dapat dilihat hal-hal yang menarik antara lain, pertama faktor transformasi budaya dan tradisi desentralisasi yang diberikan pusat kerajaan yang mendorong adanya praktik ke arah korupsi. Kedua, struktur sosial di bawah yang tidak dapat bergerak bebas karena terekploitasi oleh penguasa. Akar budaya inilah yang merefleksi ibarat cucuran air dari atap kemudian pada akhirnya jatuhnya ke pelimbahan juga. Akan tetapi, yang sangat menarik adalah realitas keberlangsungan bahwa praktik tersebut terus dan mentradisi di Indonesia sampai saat ini. Terbukanya kesempatan, peluang serta rendahnya moralitas menjadi alasan mengapa seorang oknum melakukan tindakan korupsi. Lebih runyam lagi tindakan korupsi yang telah mengakar dari lapisan atas hingga ke lapisan bawah pada masyarakat seolah-olah merupakan suatu tindakan yang wajar dan ditanggapi dengan permisif oleh masyarakat itu sendiri.

\section{PENUTUP}

\section{Perilaku Korupsi Bersifat Akut}

Perilaku korupsi disebut akut karena telah menjalar ke berbagai lini hubungan personal dan sosial, atau individual dan komunal, dengan berbagai bentuk dan modus operandi berlangsung terus menerus, sehingga dapat menyebabkan kondisi krisis baik bagi masyarakat maupun negara. Di dalam khasanah ilmu pengetahuan, khususnya bidang Arkeologi, khususnya Epigrafi, penelitian ini diharapkan dapat menambah informasi tentang keadaan sosial masyarakat Jawa Kuna, meskipun diperoleh dari sumber informasi yang berasal dari kerajaan. Model pendekatan tematik dalam menghadapi sumber data yang berupa prasasti dapat dijadikan panduan dalam penyusunan historiografi dengan bahan prasasti. Model pendekatan yang dimaksud adalah membuat penafsiran atau interpretasi terhadap teks prasasti yang dapat diduga sebagai 'perbuatan' sesuai dengan tema sosial yang diteliti. Pendekatan ini dianggap lebih mikro dan mendalam dibandingkan dengan pendekatan lain yang bersifat parsial. Pendekatan mikro selain bermanfaat bagi ilmu pengetahuan diharapkan juga bermanfaat bagi upaya apresiasi dan pemahaman terhadap sumber tinggalan budaya kuna kepada masyarakat.

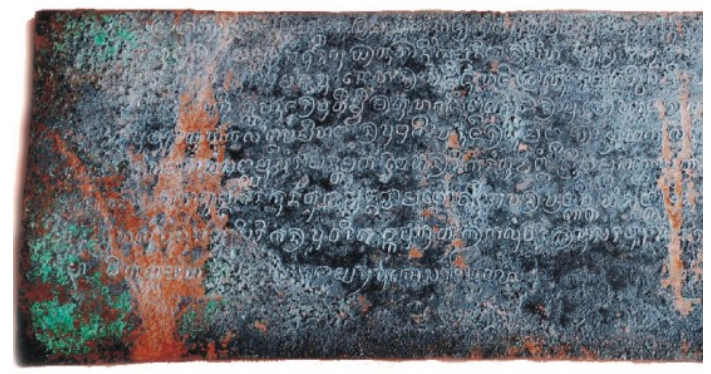

Gambar 2. Prasasti Luitan yang menceritakan mengenai pengenaan pajak atas tanah

(Sumber: http://kebudayaan.kemdikbud.go.id) 
Kajian ini telah memberikan gambaran tentang fenomena korupsi, historisitas, dan latar belakang kultural. Hasil ini diharapkan dapat memberikan (@) wawasan baru dan membuka kesadaran masyarakat untuk mengeliminasi watak dan perilaku tersebut. Berbagai faktor sosial dan kekuatan internal maupun eksternal yang mempengaruhi perilaku tersebut memberikan sumbangan pemikiran yang mampu menjadi kerangka acuan dalam upaya penyelesaian masalah (problem solving) dan solusi alternatif. Kajian ini juga dapat memberikan formulasi baru melalui jalur yang sesuai dengan kondisi budaya dan kebutuhan pengembangan SDM (Sumber Daya Manusia) yang tentunya mengarah pada sarana edukasi.

Di dalam kerangka pembangunan nasional, informasi tentang perilaku korupsi atau tindak pidana korupsi, diharapkan dapat menambah pengetahuan dan pemahaman tentang sebab-sebab munculnya korupsi, peluang munculnya korupsi, dan solusi bagi terjadinya tindak pidana korupsi, sehingga dapat mengilhami tindakan pemberantasan korupsi seperti sekarang ini yang sedang digalakkan oleh Pemerintah. Hasil penelitian ini diharapkan selain bermanfaat bagi perkembangan ilmu pengetahuan, juga dapat membantu pembangunan mental spiritual masyarakat yang terkontaminasi oleh kebiasaan bertindak, sehingga dengan mudah disebut dengan 'budaya' korupsi.

Perilaku atau tindak pidana korupsi yang telah dikenal pada masa Jawa Kuna hingga zaman modern ternyata telah menjadi akut, mengalami keberlanjutan (kontinuitas) dan kadangkadang berhenti sesaat (diskontinuitas), ketika struktur masyarakat tidak memungkinkan untuk terjadi. Fenomena korupsi ini hendaknya harus terus mendapat perhatian yang serius dalam upaya pemberantasannya, sehingga dapat ditekan menjalarnya dan bahkan dapat ditumpas, seperti telah ditunjukkan bukti-buktinya pada masa Jawa Kuna. 


\section{DAFTAR PUSTAKA}

Alatas, Syed Hussein. 1986. Sosiologi Korupsi. Jakarta: Penerbit Utama.

Anonim. 1975. Simposium Sejarah Hukum. Badan Pembinaan Hukum Nasional. Jakarta: Penerbit Erlangga.

Anonim. 1999. "Can Corruption be Measured?" dalam Banks World, Vol.3. No. 8 June. Washington DC: World Bank Group.

Bratsis, Peter. 2003. Corrupt Compared to What? : Greece, Capitalist Interests and the Specular Purity of the State. London: School of Economics and Political Science Hellionistic Observatory.

Boechari. 1966. "Preliminary report on the discovery of an Old-Malay Inscription at Sodjomerto" dalam Madjalah IImu-IImu Sastra Indonesia III No. 2-3, Oktober 1966. HIm. 241-251.

1975. "Jayapatra. Sekelumit tentang Pelaksanaan Hukum dalam Masyarakat Jawa Kuna" dalam Simposium Sejarah Hukum, Badan Pembinaan Hukum Nasional. Jakarta: Penerbit Binacipta.

Bosch, FDK. 1952. Srivijaya, Sailendra dan Sanjayawamsa. (terjemahan). Jakarta: Bhratara.

Bourguignan, Francois \& Christian Morrison. 1992. Adjusment and Equiting in Developing Countries. Paris: OECD.

de Casparis, J.G. 1950. Inscripties uit de Sailendra Tijd - Prasasti Indonesia I. Bandung: A.C. Nix \& Co.

de Graaf, Galt. 2004. "Portrait of Corruption : Towards a Contextual Theory of Corruption" dalam EGPA Annual Conference: Administering the New Europe. Slovenia.

Dwiyanto, Djoko. 1992. "Pajak dan Pembatasan Usaha di Jawa abad IX- XVI Masehi". Laporan Penelitian. Yogyakarta: Universitas Gadjah Mada.

1993. "Metode Penelitian Epigrafi dalam Arkeologi" dalam Makalah dalam Evaluasi Hasil Penelitian Epigrafi. Trowulan: Pusat Penelitian Arkeologi Nasional. 1 - 3 November 1992. HIm. 1 - 15.

1994. "Manfaat Sumber Data Arkeologi (Epigrafi) sebagai Acuan Penelusuran Harijadi Suatu Daerah" dalam Berkala Arkeologi, Tahun XIV, Edisi Khusus. HIm. 6 - 9.

2001. "Tinggalan Tertulis di Jawa Tengah" dalam Jawa Tengah: Sebuah Potret Warisan Budaya. Yogyakarta: Suaka Peninggalan Sejarah dan Purbakala Jawa Tengah dan Jurusan Arkeologi FIB-UGM. HIm. 199-205.

2003. Asal Usul dan Pengaruh Wangsa Sailendra di Pantai Utara Jawa Tengah. Makalah dalam Sarasehan Sejarah Daerah Karesidenan Pekalongan, di Pekalongan, 10 Mei 2003. 
Deflem, Mathieu. 1995. "Corruption, Law and Justice" dalam Journal of Criminal 23(3). HIm. 243-258.

Djafar, Hasan. 1978. Girindhrawarddhana. Beberapa Masalah Majapahit Akhir. Jakarta: Yayasan Dana Pendidikan Buddhis Nalanda.

Garraghan, Gilbert J. 1957. A Guide to Historical Method. East Fordham Road, New York: Fordham University Press.

Gatenby S. Hornby E. V. dan H Wakefield. 2005. The Advanced Learner's Dictionary of Current English. London: Cambridge University Press. HIm. 218.

Kubiak, Anna. 2001. Corruption in Everyday Experience: Report on Survey. Warsawa: Institute of Public Affairs.

Lopa, Baharuddin. 2002. Kejahatan Korupsi dan Penegakan Hukum. Jakarta: Penerbit Bulan Bintang.

Moore Jr., Barrington. 1965. Political Power and Social Theory. New York: Harper and Row Torchbooks. HIm. 80 - 88.

Nakada, Kozo. 1985. "A few studies on the Kingdom of Ho-ling in Java" dalam Noboru Karashima (ed.) Indus Valley to Mekong Delta, Explorations in Epigraphy. Madras: New Era Publications. HIm. 313-320.

Poerbatjaraka, R.M.Ng. 1956. Srivijaya, Sailendra dan Sanjayawamsa. (terjemahan) Jakarta: Bhratara.

Sahetapy, J.E. 1994. "Kejahatan Koorporasi” dalam Jurnal IImu-IImu Sosial No. 5, Januari 1994. Jakarta: Univesitas Indonesia,.

Soemadio, Bambang, dkk. (ed.). 1992. Sejarah Nasional Indonesia, Jilid II (Jaman Kuna). Jakarta: Departemen Pendidikan dan Kebudayaan.

Sumaryono, E. 1999. Hermeneutik: Sebuah Metode Filsafat. Yogyakarta: Penerbit Kanisisus.

Sumijati, dkk. (ed.) 2001. Jawa Tengah: Sebuah Potret Warisan Budaya. Suaka Peninggalan Sejarah dan Purbakala Jawa Tengah dan Jurusan Arkeologi, Fakultas IImu Budaya UGM.

Sumber lain:

http://www.cos.sc.edu/socy/faculty/deflem/zcorrupt.pdf 


\section{Lampiran 1:}

\section{CONTOH HASIL IDENTIFIKASI PRASASTI-PRASASTI YANG BERISI FRASA/KALIMAT YANG TERKAIT DENGAN TINDAK PIDANA KORUPSI.}

\section{Prasasti Luitan (823 C)}

\section{Isi Prasasti:}

Penduduk desa Luitan yang termasuk wilayah Kapung menghadap rakryān Mahāmantri i Hino untuk memberitahukan bahwa mereka tidak sanggup membayar pajak karena ukuran tanahnya tidak sesuai dengan yang sesungguhnya. Kemudian mereka memohon agar sawah mereka diukur kembali. Ternyata ukurannya berbeda, selisih satu setengah setiap tampahnya (hanya dua pertiga dari luas sesungguhnya)

Dalam hal ini tampak adanya pungutan pajak yang tidak sesuai dengan objek terkena pajak, sehingga memberatkan bagi warga desa Luitan. Selain itu akibatnya kelebihan setoran pajak yang telah ditarik sangat rawan untuk dimanfaatkan sebagai kepentingan pribadi (korupsi). Oleh karena itu perlulah dilakukan pengukuran ulang sehingga diperoleh ukuran yang sebenarnya dari sawah tersebut, dan menutup peluang terjadinya tindakan korup di lingkungan petugas pemungut pajak

\section{Kutipan:}

1. ...tatkāla anak wanua i luītan watak kapun manambah i rakryān mapatih i hino umajarakan pranah nikanan sawah kmitanya tan wnan mañisī uddhāea sañka ri höt nikanan sinaguh satampah kinonnakan ya ukuran de rakryān mapatih

2. muan rakryān i pagarwsi sunguh pua ya an mahot ikana tampahnya tan wnan manisi ta ru

3. an tñah in satampah muan tan wnnnya makatik 6 inata an sambah nikanan ramā masawaha lamwit 1 tampah 7 muan makatika 4 apan samankana kirakiranyan sampun I

4. nukur...

\section{Prasasti Tija}

Isi Prasasti:

Rakryān Jasun Wungkal mengadukan kepada raja berkaitan dengan tidak diserahkannya pajak di Tija kepada Nāyaka, yang dalam hal ini mungkin termasuk Jasun Wungkal sendiri. Raja kemudian memanggil awaju di manayuti yang bernama Wasana dan Dinamwan, menayakan pajak tersebut. Awaju di manayuti mengatakan bahwa pajak tersebut digunakan untuk menjamu pangurang (penarik pajak) yang meminta lebih dari yang semestinya diterima, sehingga tidak diserahkan kepada nāyaka.

Dalam hal ini telah terjadi perbedaan persepsi antara dua pihak yang berselisih tentang seberapa besar jumlah yang harus dibayarkan melalui pajak. Sebagai akibat perbedaan persepsi ini maka salah satu pihak disini berani menggunakan hasil penarikan pajak untuk keperluan yang lain yang belum tentu benar. Di sinilah peluang terjadnya tindakan penyelewengan pajak sangat terbuka lebar, karena perbedaanpersepsi tersebut, dimana masing-masing pihak menganggap benar tindakannya.

\section{Kutipan :}

Plaat II Verso

1. .....makanimitta marawarah rakryān jasun wungkal i crī mahārāja. sira ling nira pramāña irikang simma kawajwan ya

2. tan tuhagana ikang awaju ri suruhanya. āpan nāyaka para ni sadŗwya haji nikang simma kawajwan ling rakryān jasu 
3. n wungkal, tinañan pwekang awaju ri manayuti mangaran wasana dinamwan de crī mahārāja ri para ni dŗwya haji nikang sima

4. kawajwan ri tija. lawan haru haru. ikang pinupun ikang awaju ri manyuti. majar ikang awaju ri amanayuti mangaran wa

5. sana mwang dinamwan. pinaka pangiwönya irikang pangurang angasū wuwuh lingnya. Tan tinahilakěnya ring nāyaka mithya ta ngaran ika ra

6. kryān jasun wungkal yang panĕngguh mareng nāyaka dŗwya haji nikang sima kawajwan ri tija. lawan i haru haru . kahola (ĕ)

Plaat III Recto 1.

nd(e) nikang awaju ri manayuti .......

\section{Prasasti Wurudu Kidul (922 M)}

\section{Isi Prasasti:}

Gugatan seorang penduduk Wurudu Kidul yang selama ini dianggap sebagai orang asing, sehingga sebagai konsekuensinya dikenakan berbagai kewajiban termasuk di dalamnya dikenakan pajak sebagai orang asing. Hal ini tentunya telah merugikan seorang warga, dan ada kemungkinan telah menguntungkan pihak lain. Apabila tuduhan terhadap warga tersebut tidaklah benar (sebagai warga asing) tentunya yang patut dipertanggung jawabkan adalah selama ini kemanakah hasil pajak yang telah terlanjur ditarik, apakah disetorkan ke kerajaan atau justru tidak dilaporkan dan dimanfaatkan untuk kepentingan pribadi?

\section{Kutipan:}

A. 2. .......iri kā diwasa san dhanadī wwan in wurudu kidul watěk halaran winaih surat jaya

3. pātra kmitananya. sambandha sạ dhanadī inujar samgĕt manhuri mańaran wukajana. sina


padan

5. in pakarañān makabaihan tlas rumuhun ri san pamgĕt. kinonakan swa wargā

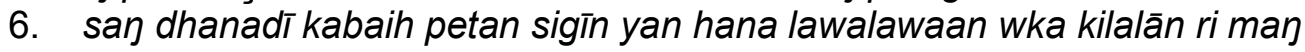

7. huri kawwïbwïtan san dhanadī .........

B. $7 . \quad$.........iri kā

8. diwaśa sań dhanadī winaih surat jayapātra kmitananya de pamgĕt juru $i$ madañdar samwandha hana sa (n) pāmāriwa ńa

9. ranya inanugrahān de samgat juru ikā wanua i manhuri makon ta rasikā ta. milala ikā kitĕra

10. $n$ i manhuri. andan kadi rakuaya tumuduh ikāsan dhanadī sinańguhnya wka kmir kunā sankā ri nāgata rasikā

11. dinalih tan ri śilanya dadiya manambah $i$ sạ tuhān $i$ pakarañān majar ya $i$ padharmanikā wuwus

12. kinirim ikā sạ kinońkon surat .........

\section{Prasasti Karang Bogem (1387 M)}

\section{Isi Prasasti:}

Penetapan daerah kekuasaan seorang patih-tambak berikut pembayaran atas pajak-pajak dan ketentuan lainnya. Selain itu terdapat keputusan tentang pungutan semacam sumbangan disebabkan kaeena ada seorang warga yang memiliki hutang yang harus dilunasinya. Yang menarik disini adalah adanya permohonan untuk dapat menarik pajak ekstra yangdisebabkan karena adanya tujuan tertentu yaitu membantu hutang dari warga lain. Sejauh dilakukan dengan benar hal tersebut malah 
mencerminkan suatu rasa kebersamaan yang positif. Tetapi dengan dimungkinkannya adanya penarikan pajak ekstra untuk kepentingan tertentu maka akan terbuka peluang juga bagi terjadinya tindak penyelewengan hasil pajak apabila berada di tangan pihak yang tidak bertanggungjawab.

\section{Kutipan:}

2. haken karange patih tamba karang bogem, pengananekidul lebuh penangane wetan sadawata anutugsagara pisan...

4. hana ta kawulaningong saking gresik warigaluh ahutang sakti rong laksa gnep sabisane hasikep rowang warigaluh luputa ta pangarah saking si

5. ddhayu kapangarahan po hiya saki dalem galangan kawolu anghaturaken ta hiya hacanbobot sewu sarahi atambak sesine

\section{Prasasti Wijaya-Parakrama-Wardana (1447 M)}

\section{Isi Prasasti:}

Penetapan perdikan, larangan bagi orang-orang tertentu untuk masuk ke tanah perdikan, jenis kejahatan. Larangan ini ditujukan agar supaya mereka yang tidak berkepentingan tidak dapat dengan seenaknya melakukan perbuatan yang merugikan warga maupun kerajaan, terutama dalam hal penyalahgunaan wewenang dan kekuasaan.

\section{Kutipan:}

Miçra-paramiçra, panhurang, padem, tukang kayu, peranakan, pedagang permata, malandang, leca, tukang masak, kutak, hamba radja,trepan, balian, sukun, haluwarak, rakasang, ramanang, pininle, katangaran, tapahaji, airhaji,manhuri, juru baraka, juru tgel, juru judi, jurujalir, juru hunjeman, juru kling, juru cina, juru gosali, tuha nimbi, tuha dagang, pinta palaku sakupang satak, hulun haji, watek I jro...

Mayang tan pawwah, walu rumambat ing natar, rah kasawar ing natar, hastacapala, wakcapala, duhilaten, amijilaken wuryyan ing kikir, mamumpang, tendas ning mas, ancapratyanca..

\section{Contoh:}

Prasasti Batu beraksara Pallawa dan Jawa Kuna di wilayah Jawa barat dan Jawa Tengah

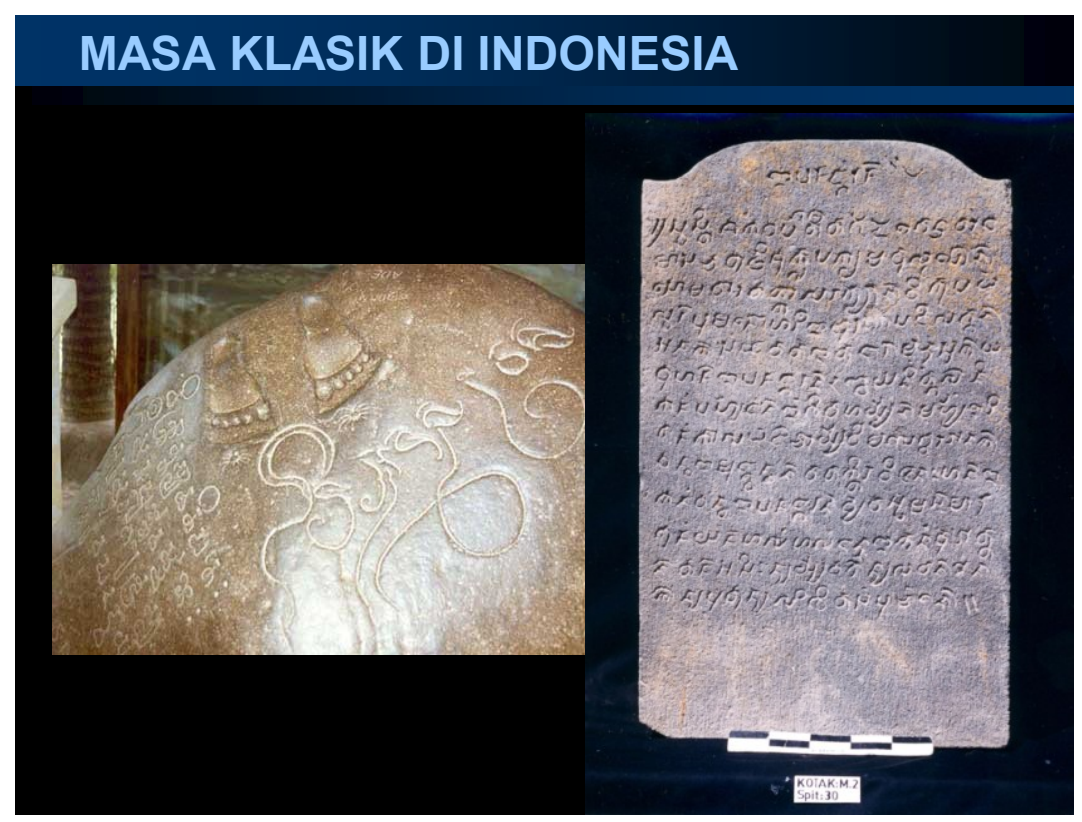



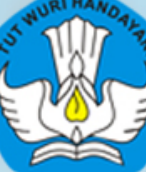

西先

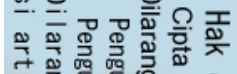

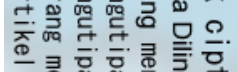

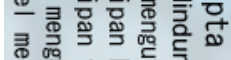

근돌.

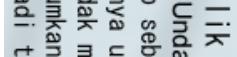

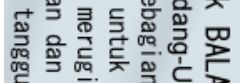

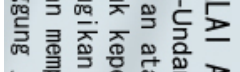

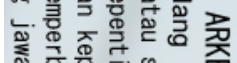

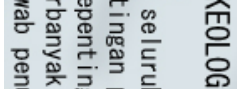

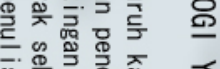

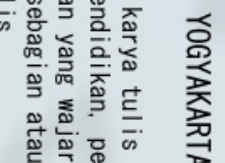

क

들.

与 웡

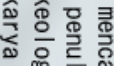

袖

क的品

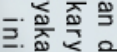

政

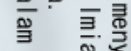

ष्ण

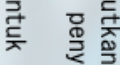

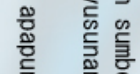

+

.

ㄱ.

政

곷

음

ธั ฒ

产 